\section{EMBRYARIDDLE}

Aeronautical University

SCHOLARLY COMMONS
Journal of Aviation/Aerospace

Education \& Research

Volume 14

Number 3 JAAER Spring 2005

Article 5

Spring 2005

\title{
Invasive Iguanas as Airstrike Hazards at Luis Munoz Marin International Airport, San Juan, Puerto Rico
}

Richard M. Engeman

Henry T. Smith

Bernice Constantin

Follow this and additional works at: https://commons.erau.edu/jaaer

\section{Scholarly Commons Citation}

Engeman, R. M., Smith, H. T., \& Constantin, B. (2005). Invasive Iguanas as Airstrike Hazards at Luis Munoz Marin International Airport, San Juan, Puerto Rico. Journal of Aviation/Aerospace Education \& Research, 14(3). https://doi.org/10.15394/jaaer.2005.1518

This Article is brought to you for free and open access by the Journals at Scholarly Commons. It has been accepted for inclusion in Journal of Aviation/Aerospace Education \& Research by an authorized administrator of Scholarly Commons. For more information, please contact commons@erau.edu. 


\title{
INVASIVE IGUANAS AS AIRSTRIKE HAZARDS AT LUIS MUÑOZ MARÍN INTERNATIONAL AIRPORT, SAN JUAN, PUERTO RICO
}

\author{
Richard M. Engeman, Henry T. Smith, and Bernice Constantin
}

Green iguanas are large lizards exotic to Puerto Rico, but abundant around Luis Muñoz Marín International Airport (SJU) in metropolitan San Juan, where we assessed their potential as an airstrike hazard. During our two month sampling period, operations on portions of the airfield had to be halted on six occasions due to hazards presented by iguana incursions to aircraft traffic areas. All 5 records of collisions with iguanas in the FAA airstrike database were from SJU. Body size comparisons between mature iguanas and terrestrial mammals known as aircraft collision hazards indicated that iguanas present airstrike hazards. Application of a predictive equation previously developed to relate body mass to a relative hazard score for airstrikes indicated that iguanas could rank with such damaging species as ducks, pelicans and eagles. We recommend that a wildlife hazard assessment be conducted at SJU, and we suggest some possible remediation measures.

The green iguana (Iguana iguana) is an exotic species that has become well-established in Puerto Rico (e.g., Thomas, 1999). One of the locations in Puerto Rico where green iguanas are abundant is at Luis Murioz Marín International Airport (SJU) in metropolitan San Juan. Collisions between aircraft and wildlife are a worldwide issue because they threaten passenger safety (Thorpe, 1997), result in lost revenue and costly repairs to aircraft (Milsom \& Horton, 1990; Linnell, Conover \& Ohashi, 1996; Robinson, 1997; Cleary \& Dolbeer, 1999; Cleary, Wright \& Dolbeer, 1997; Cleary, Wright \& Dolbeer, 1998), and can erode public confidence in the air transport industry as a whole (Conover, Pitt, Kessler, Dubow, Sanborn, 1995). Exotic species frequently impose negative impacts to native species and habitats. However, in the case of the green iguana in Puerto Rico, we describe the potential airstrike hazard that this exotic lizard poses at SJU.

\section{METHODS}

\section{Airport description}

SJU is a public facility located along the northern coast of Puerto Rico in the northeastern metropolitan San Juan area, $14 \mathrm{~km}$ east of San Juan proper. SJU is $2.7 \mathrm{~m}$ above mean sea level with maritime tropical climatic conditions. SJU services commercial air carrier (46\%), commuter $(36 \%)$, general aviation $(16 \%)$, and military aircraft (1\%) (airnav.com). SJU averages 638 operations (defined as any takeoff or landing by a fixed-wing aircraft) per day (ca. 233,000/yr). Habitat bordering the airport boundaries includes manicured lawns, dense tropical vegetation, and mangrove wetlands. Inside the airfield boundaries, the habitat includes manicured grass, patches of topical trees, buildings, and paved surfaces.

\section{Airport records}

A runway incursion is defined by the Federal Aviation Administration (FAA) as "Any occurrence at an airport involving an aircraft, vehicle, person, or object on the ground that creates a collision hazard or results in a loss of separation with an aircraft taking off, intending to take off, landing or intending to land" (Chamberlain, 2000). Our work was initiated in fall of 2001 by examining the "Daily Record of Facility Operation" for the months of October and November of 2001 . Any changes in airport operations due to iguana runway incursions would be reported in these documents. The frequency with which operations are altered due to wildlife intrusions is an indicator of airstrike hazard, and also can be indicative of economic losses due to delays from clearing incursions, even if a strike does not take place. Wildlife strike database

The definition of a wildlife strike by Bird Strike Committee Canada (Transport Canada, 1992) has been adopted by federal, civilian, and international organizations, including the FAA. A wildlife strike is recorded if: (1) a pilot reports a strike, or (2) aircraft maintenance personnel identify damage as having been caused by a wildlife strike, or (3) personnel on the ground report seeing an aircraft strike one or more animals, or (4) animal remains, in whole 
or part, are found on any airside pavement area or within 200 feet of a runway, unless another reason for the animal's death is identified. Wildlife strike data provide valuable information on wildlife hazards at airports, including the types of wildlife struck, seasonality, and time of day. Wildlife strike rates, strikes per 10,000 aircraft operations (Blokpoel, 1976), are used as indices of wildlife hazards at airports, and for assessing hazard abatement efforts. Statistics on wildlife strikes with aircraft in the U.S. are compiled by the FAA using their Form 5200-7, Bird/Other Wildlife Strike Report (e.g., Cleary, Wright \& Dolbeer, 1996; Cleary \& Dobeer 1999; USDA, 1998). We examined the FAA airstrike data base to identify whether there has been a precedent for iguanas, or other large lizards, as an airstrike hazard.

\section{Iguana morphology and damage potential}

To complement any information existing in the FAA data base on iguanas as an airstrike hazard, we examined the morphological characteristics of terrestrial animals found in the literature as being more commonly involved in collisions with aircraft that also might be similar in size to iguanas. This information would allow an assessment of the potential damage that iguanas could inflict in a strike. In addition, Dolbeer, Wright \& Cleary (2000) used data from 19 bird and 2 mammal species to develop an exponential regression model relating wildlife body mass to a relative hazard score for airstrikes. We applied this equation for the body mass of mature iguanas to estimate a relative hazard score, and, by extension, compare their damage potential to animals well-known as airstrike hazards.

\section{Airport records}

\section{RESULTS}

Three times in October and 3 times in November, incursions by iguanas caused activity to be halted on portions of the airfield. These records do not reflect the number of times that iguanas may have encroached on areas of aircraft operations. Rather, these records indicate the frequency that pilots, tower or ground personnel observed iguanas and judged them to be in position to present a hazard for a collision with an aircraft.

\section{FAA airstrike database}

Only 5 strikes in the FAA database were attributed to iguanas (the only lizard recorded), and all were from SJU. Therefore, comparative information was not available on iguanas, or other large lizards, as air strike hazards from other airfield situations. Most airports account for less than $20 \%$ of actual strikes (Dolbeer, Wright \& Cleary, 1995).
Wildlife strike statistics based on pilot reports generally are incomplete, because pilots either do not report strikes or the proportion of reported strikes varies due to factors such as decreased pilot acuity towards wildlife during critical phases of flight, size of the animal, group size, weather conditions, time of day, or heightened pilot awareness during migratory seasons (Linnell, Conover \& Ohashi, 1999). Thus, it is logical to assume that the same holds true for SJU, and that more strikes of iguanas may have occurred than have been reported.

\section{Iguana morphology and damage potential}

Green iguanas grow to $2 \mathrm{~m}$ in length and $4-5 \mathrm{~kg}$ in weight (Ashton \& Ashton, 1988; Distel \& Veazey, 1982; Savage, 2002). Due to the limited history of iguanas as an airstrike hazard, information does not exist on the damage impacts from iguanas to aircraft. Therefore, we examined the potential for damage caused by, comparable-sized terrestrial mammals for which data has been collected. Foxes and coyotes (Canis latrans) are animals in a similar size class as mature iguanas that have been identified as commonly hazardous to aircraft (USDA, 1998). Coyotes, at about $1.2 \mathrm{~m}$ and $12-14 \mathrm{~kg}$ (Mumford \& Whitaker, 1982), average a little shorter, but heavier than green iguanas. Red foxes (Vulpes vulpes) at $4-4.9 \mathrm{~kg}$ and $0.95-1.05 \mathrm{~m}$, and gray foxes (Urocyon cinereoargenteus) at $4-4.3 \mathrm{~kg}$ and 0.92 - $0.94 \mathrm{~m}$ (Mumford \& Whitaker, 1982) are optimal comparisons on the basis of mass, but are much shorter than mature iguanas. Coyotes ranked fifteenth of all wildlife species in the United States, and second next to deer among terrestrial species, in terms of the percentage of strikes that resulted in damage to the aircraft (Dolbeer et al. 2000). However, a ranking similar to that of coyotes for the percent of strikes resulting in damage was not given for foxes (Dolbeer et al. 2000).

Application of 4 and $5 \mathrm{~kg}$ weights to the exponential regression equation of Dolbeer et al. (2000) yielded respective relative hazard scores of 39 and 42 for iguanas. As a comparison, the relative hazard score was 37 for ducks, 44 for pelicans, 31 for eagles, 25 for hawks (buteos), and 48 for cranes (Dolbeer et al. 2000). Cranes ranked fourth, pelicans ranked fifth, ducks ranked seventh, eagles ranked eighth, and hawks ranked ninth among the list of species for the percentage of strikes that resulted in damage to the aircraft (Dolbeer et al. 2000). When considered with these taxa, iguanas again show a high potential for destructive airstrikes. 


\section{DISCUSSION}

\section{Wildlife hazard assessment}

Many actions can decrease wildlife hazards, depending on the species, time of year, and habitat characteristics on and around the airfield. Wildlife hazard assessments provide the framework through which a site-specific understanding of wildlife hazards on an airport are developed (Cleary \& Dolbeer, 1999; USDA, 1998; Servoss, Engeman, Fairaizl, Cummings \& Groninger 2000). Wildlife hazard assessments typically should cover at least one full year because wildlife populations exhibit seasonal fluctuations in behavior and abundance (Servoss et al. 2000). Such an assessment at SJU would provide detailed information on abundance, location, and seasonality of iguana (and any other wildlife) activity around the airfield. A wildlife hazard assessment should also include runway sweeps for wildlife carcasses, as this would result in a more accurate picture of strike rates for iguanas, and other animals (e.g., Servoss et al. 2000).

\section{Potential management actions}

A wildlife hazard assessment should be completed prior to formulating management strategies to reduce the probability of a strike. Nevertheless, we can consider some of the possible remedies that might be applied at SJU. First, green iguanas were typically found in association with vegetative cover, usually in the form of trees. They frequently bask on the runways or adjacent verges and quickly dart into tall vegetative cover at even a distant approach. Thus, habitat modification would appear to be one avenue for reducing the number of incursions to the runways (see Cleary \& Dolbeer, 1999 for a general discussion on habitat modification as an airfield management practice). Removal of vegetative cover within SJU and along perimeter fences could reduce the attractiveness of those areas for iguanas. As a consequence of removing refugia, fewer iguanas would be available to seek runway areas for basking. In addition, if a wildlife hazard assessment indicates that the airfield attraction for iguanas includes suitability of the soils adjacent to runways as nesting habitat, then other habitat modifications such as soil cementing might deter nest building and reduce the number of runway incursions.

Another management possibility might be to exclude iguanas from the nunway areas (see Cleary \& Dolbeer, 1999 for a general discussion on exclusion of wildlife as an airfield management practice) using a means such as electric fencing. Experimentation would probably be required to identify a design and placement generally effective for iguanas. Regular maintenance would be required to avoid breaches, and hurricanes could cause severe damage to such a system. However, one advantage of such a system is that other potentially problematic species, such as feral dogs (Canis familiaris) and cats (Felis catus) also could be deterred from runway areas.

A final, but obvious, approach for reducing the number of incursions would be population reduction (see Cleary \& Dolbeer, 1999 for a general discussion on population reduction as an airfield management practice). Because the green iguana is an invasive species in Puerto Rico, there probably are few regulatory concerns for their removal. However, the removal would have to be an ongoing process to counter reproduction by remaining iguanas and to counteract re-invasive pressures back into the airfield area.

Implications

Green iguanas are large enough, common enough at SJU, and exhibit behavior (basking on runways) that make them a legitimate airstrike hazard at SJU. On the basis of mass, they compare to ducks and pelicans in relative hazard score. Based on other terrestrial airstrike hazard species (mammals), the aircraft components most likely to be damaged by collisions with iguanas are the landing gear, propeller, wing/rotor and engine, with approximately $19 \%$ of strikes likely to result in minor to substantial damage (Cleary \& Dolbeer 1999). A wildlife hazard study would help clarify the problem and identify management remedies. Beyond SJU, it is possible that green iguanas eventually will be identified as hazards at other U.S. airports. Green iguanas have become established in south Florida (Ashton \& Ashton, 1988; Bartlett \& Bartlett, 1999; Conant \& Collins, 1991; Dalrymple, 1994), and we have personally observed mature iguanas near the runway at Homestead Air Reserve Base 33 $\mathrm{km}$ southeast of Miami. That airfield receives substantial use by fighter aircraft, including weapons training deployment and several exercises each year involving joint service fighter and mission support aircraft (Engeman, Peterla \& Constantin, 2002). Military flights are particularly vulnerable to wildlife strikes (Blokpoel, 1976), and this situation should be monitored as part of that airfield's Bird Air Strike Hazards (BASH) program. Because of the locations in Florida where green iguanas are wellestablished (Bartlett \& Bartlett, 1999), large commercial airports around Miami, and perhaps Tampa, should also be alert for developing populations of iguanas around the airfields. $t$ 
Richard Engeman is a $\mathrm{PhD}$ research biometrician at the National Wildlife Research Center, the only U.S. federal facility dedicated entirely to researching practical and environmentally responsible solutions to human-wildlife conflicts. He has been an author of many scientific papers, including on wildlife-airstrike hazards. Dr. Engeman has also has authored numerous papers on problems caused by invasive species, including many on invasive reptiles.

Henry Smith is a District Biologist for Wildlife Resources with the Florida Park Service overseeing 24 state parks, and an Affiliate Research Assistant Professor at Florida Atlantic University, Wilkes Honors College. He has worked extensively with damage caused by exotic species, and he has authored many papers on invasive lizards.

Bernice Constantin is the Florida and Puerto Rico State Director for USDA/Wildlife Services (WS), the only U.S. federal agency with its mandate to resolve human-wildlife conflicts. He oversees all WS operations in Florida and Puerto Rico, which includes many contracts for reducing wildlife-airstrike hazards at airports throughout both regions. 


\section{REFERENCES}

AIRNAV.COM. Luis Muñoz Marin International Airport, Puerto Rico. http://www.airnav.com/airport/TJSJ.

Ashton, R.E., Jr. \& Ashton, P.S. (1988). Handbook of Reptiles and Amphibians of Florida: Part Two, Lizards, Turtles and Crocodilians. Miami: Windward Publishing.

Bartlett, R.D. \& Bartlett, P.P. (1999). A Field Guide to Florida Reptiles and Amphibians. Houston: Gulf Publishing.

Blokpoel, H. (1976). Bird hazards to aircraft. Buffalo: Books Canada Inc.

Chamberlain, H.D. (2000). Runway incursion is no accident. FAA Aviation News. $11 \mathrm{pp}$.

Cleary, E.C. \& Dolbeer, R.A. (1999). Wildlife hazard management at airports. Washington, D.C.: Federal Aviation Administration and U.S. Dept. Agriculture/Wildlife Services.

Cleary, E.C., Wright, S.E. \& Dolbeer, R.A. (1996). Wildlife strikes to civil aircraft in the United States 1993-1995. (Report DOT/FAA/AS/96-3). 10pp.

Cleary, E.C., Wright, S.E. \& Dolbeer, R.A. (1997). Wildlife strikes to civil aircraft in the United States 1992-1996. (Report DOT/FAA/AS/97-3). 30pp.

Cleary, E.C., Wright, S.E. \& Dolbeer, R.A. (1998). Wildlife strikes to civil aircraft in the United States 1991-1997. (Report DOT/FAA/AS/98-4). 34pp.

Conant, R. \& Collins, J.T. (1991). A Field Guide to Reptiles and Amphibians, Eastern and Central North America. Boston: Houghton Mifflin.

Conover, M.R., Pitt, W.C., Kessler, K.K., Dubow, T.J. \& Sanborn, W.A. (1995). Review of data on human injuries, illnesses, and economic losses caused by wildlife in the United States. Wildlife Society Bulletin. 23, 407-414.

Dalrymple, G.H. (1994). Non-indigenous amphibians and reptiles in Florida. Pp 67-78 in An Assessment of Invasive NonIndigenous Species in Florida's Public Lands. Technical Report No. Tss-94-100. Tallahassee: Florida Dept of Environmental Protection.

Distel, H. \& Veazey, J. (1982). The behavioral inventory of the green iguana, Iguana iguana. pp 252-270. In (G. Burghart and A.S. Rand, eds) Iguanas of the World: Their Behavior, Ecology and Conservation. Park Ridge, NJ.: Noyes Publishing.

Dolbeer, R.A., Wright, S.E. \& Cleary, E.C. (1995). Bird and other wildlife strikes to civilian aircraft in the United States, 1994. (Interim report DTFA011-91-Z-02004. US Dept. of Agric. For Fed. Aviation Admin., FAA Technical Center, Atlantic City, NJ). 37pp.

Dolbeer, R.A., Wright, S.E. \& Cleary, E.C. (2000). Ranking the hazard level of wildlife species to aviation. Wildlife Society Bulletin. 28, 372-378.

Engeman, R.M., Peterla, J. \& Constantin, B. (2002). Methyl anthranilate aerosol for dispersing birds from the flight lines at Homestead Air Reserve Station. International Biodeterioration and Biodegradation. 49, 175-178.

Linnell, M.A., Conover, M.R. \& Ohashi, T.J. (1996). Analysis of bird strikes at a tropical airport. Journal of Wildlife Management. 60, 935-945.

Linnell, M.A., Conover, M.R. \& Ohashi, T.J. (1999). Biases in bird strike statistics based on pilot reports. Journal of Wildlife 
Invasive Iguanas

Management. 63, 997-1003.

Milsom, T.P., \& Horton, N. (1990). Birdstrike: an assessment of the hazard on UK civil aerodromes from 1976-1990. (UK Bird Strike Avoidance Team). 355pp.

Mumford, R.E. \& Whitaker, J.O. (1982). Mammals of Indiana. Bloomington, IN: Indiana University Press.

Robinson, M. (1997). The potential for significant financial loss resulting from aircraft bird strikes in or around an airport. Boston: Bird Strike Committee.

Savage, J.M. (2002). The Amphibians and Reptiles of Costa Rica. Chicago: Univ. Chicago Press.

Servoss, W., Engeman, R.M., Fairdizl, S., Cummings, J.L. \& Groninger, N.P. (2000). Wildlife hazard assessment at Phoenix Sky Harbor International Airport. International Biodeterioration and Biodegradation. 45, 111-127.

Thomas, R. (1999). The Puerto Rico area. pp 169-179 In B.I. Crother (ed) Caribbean Amphibians and Reptiles. San Diego: Academic Press.

Thorpe, J. (1997). The implications of recent serious bird strike accidents and multiple engine ingestions. Boston: Bird Strike Committee.

Transport Canada. (1992). Operating definitions - bird and mammal control. Rep. AKP5158-36-20-51 Ottawa: Environmental Services, Airports Group, Transport Canada.

U.S. Department of Agriculture. (1998). Managing Wildlife Hazards at Airports. Washington, DC: USDA/Marketing and Regulatory Programs/Animal and Plant Health Inspection Service/Wildlife Services. 